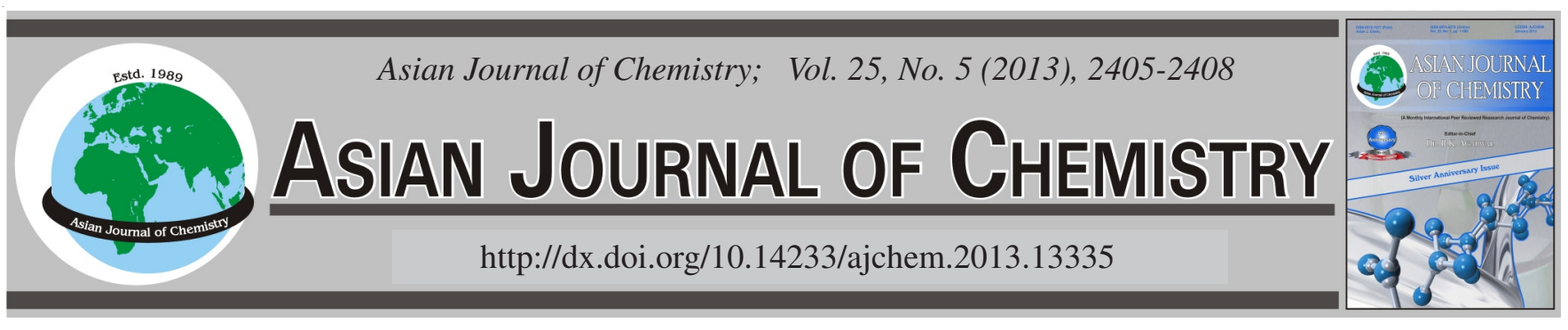

\title{
Chemical Composition of Essential Oils Derived from Eucalyptus and Lemongrass and Their Antitermitic Activities Angainst Microtermes mycophagus (Desneux).
}

Farkhanda Manzoor ${ }^{1, *}$, Narjis Naz ${ }^{2}$, SaAdiya A. Malik ${ }^{1}$, SAmra Arshad $^{1}$ and Bina Siddiqui ${ }^{3}$

${ }^{1}$ Department of Zoology, Lahore College for Women University, Lahore, Pakistan

${ }^{2}$ Department of Chemistry, Lahore College for Women University, Lahore, Pakistan

${ }^{3}$ HEJ Research Institute, Karachi, Pakistan

*Corresponding author: E-mail: doc_farkhanda@yahoo.com

(Received: 27 December 2011;

Accepted: 7 November 2012)

AJC-12369

\begin{abstract}
The essential oils of eucalyptus (Eucalyptus citriodora) and lemon grass (Cymbopogon citratus) were analyzed by GC-MS and tested against economically important termite species of Pakistan i.e., Microtermes mycophagus (Desneux). Their physical parameters were also scanned. The major constituents identified in eucalyptus oil are: eucalyptus, limonene, terpinen-4-ol, gravenone, $n$-tetradecane, 2,2'6,6'tetramethyl piperidin-4-ol, piperitone and the chemical components of lemon grass oil are: myrcene, citronellol, citral, nerol and neric acid. The repellency, toxicity, fumigation activities of test oils and tunneling behaviours of M. mycophagus were evaluated. At $25 \mu \mathrm{g} / 10 \mu \mathrm{L}$ oil concentration, lemon grass showed $63.33 \%$ and eucalyptus oil showed $62.22 \%$ mortality and at the same concentration, the repellency test revealed that both eucalyptus and lemon grass oils showed efficient repellency i.e., 42.6 and $36.33 \%$ respectively. Fumigation results revealed that lemon grass caused $100 \%$ mortality at $5 \mathrm{ppm}$ concentration on $9^{\text {th }}$ day of treatment whereas eucalyptus gave same result in the end of test period (day 12). When tunneling behaviour was observed for M. mycophagus, the average time to cross the tube at $50 \mu \mathrm{g}$ was 28 and $50 \mathrm{~h}$ in eucalyptus and lemon grass oil one-to-one.
\end{abstract}

Key Words: Anti-termitic activity, Eucalyptus, Lemongrass, Microtermes mycophagus (Desneux).

\section{INTRODUCTION}

Essential oils extracted from aromatic plants have been used since ancient times as safe condiment or spice, in flavour and fragrances in medicines and to combat against microbes and to prevent or keep stored agricultural products safe from insects ${ }^{1-4}$. Essential oils are successful alternatives to insecticides without causing any danger to the environment ${ }^{5-7}$. Biological compounds with improved insecticidal properties and being non-toxic or only mildly toxic to humans are needed on constant basis ${ }^{2}$.

Microtermes mycophagus (Desneux) is a subterranean termite species that infests commercially important timber species like Dalbergia sissoo, Cedrus deodara, Mangifera indica, Zyziphus spp, Morus spp. and Acacia spp, attacking logs and stumps, causing a lot of damage to forests, wooden structures and buildings. This species has also been reported as agricultural pest of nurseries, vegetables and sugarcane field ${ }^{8-11}$.

Essential oil obtained from the leaves of Eucalyptus citriodora belonging to the family Myrtaceae, is used as a pesticidal agent and as insect repellent ${ }^{12}$. Lemon grass (Cymbopogon citratus), member of family Poaceae (Gramineae), is a local grass native to India, Sri Lanka and Pakistan.
The present study is the continuation of our research work $^{13}$ to test the different essential oils as potential termiticides and to detect the constituent profile of these oils by GC-MS, so eucalyptus and lemon grass oils are assessed as insect repellent, toxicant and fumigant against $M$. mycophagus (Desneux).

\section{EXPERIMENTAL}

Test essential oils: Reverse Dean-Stark method was used for steam distillation of the essential oils from the leaves of E. citriodora and $C$. citratus. The percentage yield of each essential oil was determined.

Oils were also tested for physical parameters such as solubility, specific gravity, refractive index, acid value and ester value.

GC-MS analysis: GC-MS of Varian, Saturn model 2000, equipped with ion trap detector (ITD) was used for the detection of various components of essential oils. Sample was injected on a DB-5MS $(30 \mathrm{~m} \times 0.25 \mu \mathrm{m}$ id, $0.25 \mu \mathrm{m}$ film thickness $)$ column. Helium (carrier gas) with a flow rate of $1.0 \mathrm{~mL} / \mathrm{min}$ and split ratio 1:5 was used. The temperature of column was maintained at $50{ }^{\circ} \mathrm{C}$ at start for $3 \mathrm{~min}$ with a $4{ }^{\circ} \mathrm{C}$ rise/min to 
$180^{\circ} \mathrm{C}$. Potential components of the test oils were recognized by their retention time and peak enhancement with standard samples in gas chromatographic mode and MS library search from the derived mass fragmentation pattern of various components of the essential oil.

Collection of termites: The workers and soldiers of $M$. mycophagus (Desneux) were collected using the tissue paper traps with sugarcane piece as bait attractant. Termites (workers and soldiers) were isolated and kept in plastic boxes with moist filter paper. Before treatment with oil, healthy termites were maintained in the laboratory at $26 \pm 2{ }^{\circ} \mathrm{C}, 80 \%$ relative humidity in constant darkness, which were used for the experimentation.

Experimental protocols: Repellency, toxicity, tunneling bioassays fumigation test with slight modification were conducted as reported in literature ${ }^{14,15}$.

Experimental conditions: All the experimental units for each type of bioassay were kept in climatic room maintained at $28{ }^{\circ} \mathrm{C}$ and $80 \%$ relative humidity at constant darkness.

Repellency Test: A Petri dish $(5 \mathrm{~cm}$ in diameter and $1 \mathrm{~cm}$ high) with 2 filter paper disks ( $1 \mathrm{~cm} \mathrm{dia,} 0.78 \mathrm{~cm}^{2}$ area) attached at opposite ends of the dish with $1 \mu \mathrm{L}$ dichloromethane was used. One of the 2 disks was treated with $0.3 \mathrm{~mL}$ of 1,5 , or 25 $\mu \mathrm{g} / 10 \mu \mathrm{L}$ concentrations of essential oils and evaporated for $0.5 \mathrm{~h}$ to remove the solvents. Control disks were treated with $10 \mu \mathrm{L}$ of ethanol only and evaporated. Each treatment dose was replicated 3 times. Ten workers were released in the centre of each Petri plate. These plates were placed in a climatic room. The distribution of termites was recorded every $15 \mathrm{~min}$ for $5 \mathrm{~h}$. Twenty observations were taken. The numbers of termites on the untreated and treated sides were calculated. The recorded data was analyzed.

Toxicity test: Filter paper disks (40 mm dia) were ovendried and weighed prior to the treatment application. 1, 5, 10, 15 and $25 \mu \mathrm{g} / \mathrm{cm}^{2}$ of essential oil treatments on the disks was made. The dilutions were topically applied on Whatmann filter paper No.1. Solvent treated filter papers were used as control. Allowed the complete evaporation of solvent at room temperature ( $65 \%$ relative humidity, $20{ }^{\circ} \mathrm{C}$ ); then the filter papers were placed in a $50 \times 9 \mathrm{~mm}$ Petri plates over a thin layer of moist sand. Thirty active termites were released into the Petri plate containing filter paper disks treated with the test material. The covered Petri dishes were then kept in climatic room. Dead termites were removed by forceps after every counting. After 8 days the non-consumed filter papers were removed, cleaned of debris, oven dried and weighed to determine the consumption. Live termites would be counted to determine mortality. The rates of mortality were examined daily up to 8 days. Three replicates for each concentration of oils including control were prepared and the data was recorded for further statistic procedures.

Fumigation test: The reported method ${ }^{15}$ with some modifications was used to evaluate the vapour action of essential oils against species of termites $H$. indicola. Tall cylindrical glass containers (inside volume $880 \mathrm{~cm}^{3}$ ) were used. The size of filter paper used was according to the dimension of the Petri dishes. It was moistened with distilled water and placed in the Petri dish at the bottom of each container. Twenty five termite workers were released in this Petri dish. A 4.25 $\mathrm{cm}$ diameter filter paper was treated with test oil to produce a concentration $5 \mathrm{ppm}$. This filter paper was suspended from the lid of the container with the help of a thread in order to avoid contact with the termites after allowing the ethanol to evaporate completely. For control, the suspended filter paper was treated with ethanol alone evaporated and then suspended in the control set. The mortality was checked regularly. Each oil treatment was replicated for 3 times. Based on the mortality rate, the oils were classified as toxic without contact or not.

Tunnelling bioassay: Three compartment tunneling test apparatus was designed for this bioassay. The first compartment was a plastic vial containing moistened but untreated soil. The second compartment was a $10 \mathrm{~cm}$ long tygon tube, containing oil treated soil linked the two plastic vials and third one was another vial containing untreated sand. About $5 \mathrm{~g}$ sand moistened with $1 \mathrm{~mL}$ of distilled water was placed in each of the two $30 \mathrm{~mL}$ plastic vials with lids. The vials were connected with a tygon tube filled with sand treated with $0,1,5$ and $25 \mu \mathrm{g} / 10$ $\mu \mathrm{L}$ concentrations of test compounds. The solvent was evaporated from the treated sand. Each treatment dose was replicated 3 times and in each controls no treatment. Thirty workers were released into one of the vials allowing them to travel to treated zone and through the whole apparatus as well. Tunneling activity was noted daily. A test was terminated once termites tunnelled all the way through the tube.

\section{RESULTS AND DISCUSSION}

The physical characteristics such as colour, odour, specific gravity, refractive index, yield, solubility, acid value and ester value of both essential oils i.e., Eucalyptus oil (Eucalyptus citriodora) and lemon grass oil (Cymbopogon citratus) were determined as shown in Table- 1 . The percentage yield of essential oil was determined i.e., $0.24 \%$. Literature reported ${ }^{16}$ that fresh lemon grass contain $0.26-0.525 \%$ essential oil. The yield of essential oil of $C$. citratus was found very close to the $\%$ yield reported.

TABLE-1

PHYSICO-CHEMICAL INVESTIGATION OF ESSENTIAL OIL OF EUCALYPTUS (Eucalyptus citriodora) AND LEMONGRASS (Cymbopogon citratus)

\begin{tabular}{clll}
\hline $\begin{array}{c}\text { S. } \\
\text { No. }\end{array}$ & Physical Properties & $\begin{array}{l}\text { Eucalyptus } \\
\text { citriodora }\end{array}$ & $\begin{array}{l}\text { Cymbopogon } \\
\text { citratus }\end{array}$ \\
\hline 1 & Colour & Greenish (light) & Pale sherry \\
2 & Odour & Lemon scented & $\begin{array}{l}\text { Pungent } \\
3\end{array}$ \\
Yield & $0.74 \%$ & $0.24 \%$ \\
4 & Solubility in alcohol & 1.3 to 1.5 vol. & $\begin{array}{l}\text { Soluble in } 70 \% \\
\text { alcohol }\end{array}$ \\
5 & (70\%) & 0.8670 at $20^{\circ} \mathrm{C}$ & 0.846 at $20{ }^{\circ} \mathrm{C}$ \\
6 & Reecific gravity & 1.4550 & 1.474 \\
7 & Acid value & - & 3.116 \\
8 & Ester value & 12 to $45 \%$ & 2.244 to $12.1 \%$ \\
\hline
\end{tabular}

GC-MS analysis of eucalyptus oil and lemon grass oil revealed the presence of different components reported in Table-2 and also established by the literature ${ }^{17-19}$. These components individually or in combination with others, may be the potential termiticidal agents.

The number of termites, M. mycophagus exposed to different concentrations of eucalyptus oil (E. citriodora) and 
TABLE-2

GC-MS ANALYSIS OF ESSENTIAL OILS OF EUCALYPTUS (Eucalyptus citriodora) AND LEMONGRASS (Cymbopogon citratus)

\begin{tabular}{cll}
\hline S. No. & Components identified in eucalyptus oil & Components identified in lemon grass oil \\
\hline 1 & 1,3,3-Trimethyl-2-oxabicyclo[2.2.2]octane(eucalyptus) & 7-Methyl-3-methylene-1,6-octadien(myrcene) \\
2 & 1-Methyl-4-(1-methylethenyl)-cyclohexene(limonene) & 3,7-Dimethyloct-6-en-1-ol (citronellol) \\
3 & 3-Cyclohexen-1-ol(terpinen-4-ol) & 3,7-Dimethylocta-2,6-dienal (citral) \\
4 & 3-Methyl-5-propylcyclohex-2-en-1-one (gravenone) & (Z)-3,7-dimethyl-2,6-octadien-1-ol( nerol) \\
5 & $n$-Tetradecane & (2Z)-3,7-Dimethyl-2,6-octadienoic acid(neric acid) \\
6 & 2,2 6,6 & \\
7 & 6-Tetramethyl piperidin-4-ol & \\
\hline
\end{tabular}

lemon grass oil (C. citratus) in ethanol solvent were recorded to test the repellent effect of oils. Graphical presentation of the results depict that both essential oils tested had excellent repellent activity against the workers of $M$. mycophagus (Desneux) at concentration of $25 \mu \mathrm{g} / 10 \mu \mathrm{L}$ in $5 \mathrm{~h}$ treatment while a significant repellency was marked in two other treatments of the both test oils as compared to the untreated disks (Fig. 1).
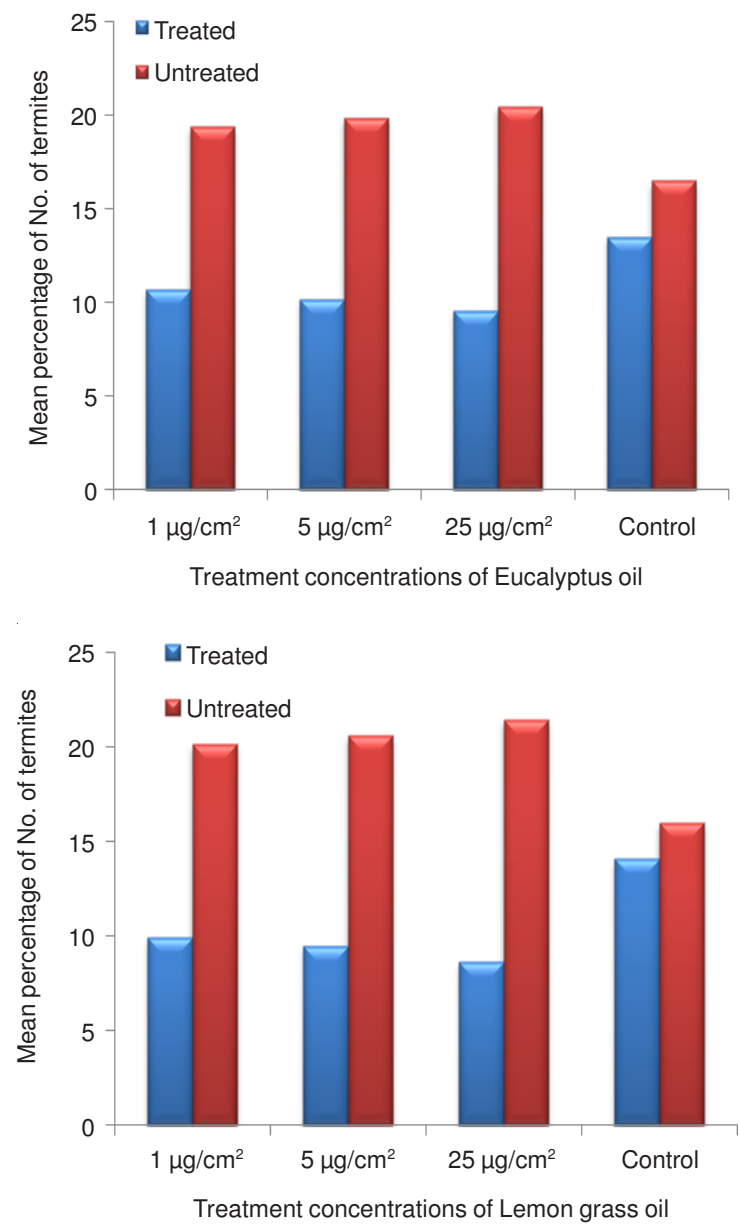

Fig. 1. Bar charts showing the repellency test results of different treatments of eucalyptus oil (Eucalyptus citriodora) and lemon grass oil (Cymbopogon citratus) against workers of M. mycophagus (Desneux)

In toxicity test, two parameters i.e., feeding and mortality were assessed for test essential oils against M. mycophagus (Desneux). The weight loss provided a measurement of termite consumption rate. As can be seen from Table- 3 essential oils tested were highly toxic against workers of $M$. mycophagus (Desneux) at dosage of $25 \mu \mathrm{g} / 10 \mu \mathrm{L}$, thus mean weight loss of filter paper after 9 days of treatment was very low in eucalyptus and lemon grass oil treatments. However, the filter paper consumption by the workers of $M$. mycophagus seems to decrease with the increase in oil concentration. The analysis of variance revealed significant difference in percentage mortality of $M$. mycophagus (Desneux) among different concentrations of both test oils $(\mathrm{F}=1.061$, df $=2,15 ; \mathrm{P}=$ 0.0001). $\mathrm{LC}_{50}$ values (calculated through EPA probit analysis program) for $M$. mycophagus (Desneux) against eucalyptus and lemon grass after nine days of treatment are also presented in Table-3.

The fumigation test results manifest that Eucalyptus oil and Lemon grass oils substantiated the repellency and toxicity against $M$. mycophagus, as can be perceived from Table- 3 both oils tested were capable of killing all workers of $M$. mycophagus (Desneux) at 5 ppm dosage after 9 days. It was revealed from analysis of variance that there were significant differences between percentage mortality of $M$. mycophagus (Desneux) among both essential oils ( $\mathrm{F}=0.00914, \mathrm{df}=2,12 ; \mathrm{P}=0.9909)$.

When tunneling behaviour of $M$. mycophagus (Desneux) was observed through the apparatus designed, the results revealed that the tested oils i.e. eucalyptus oil (E. citriodora) or lemon grass oil (C. citratus) did not affect tunneling activity at $0,5,25$ and $50 \mu \mathrm{g} / \mathrm{g}$ and the termites tunneled through the tubes in all cases. In case of highest concentration treatment i.e. $50 \mu \mathrm{g} / \mathrm{g}$ lemon grass oil, for those termites that completely crossed the tubes, it took them an average of $50 \mathrm{~h}$. However, for eucalyptus oil the average time to cross the tube was $28 \mathrm{~h}$ at the same concentration. In both oil treatments the termites became sluggish to moribund after crossing the tunnel. In control no termite mortality was observed and tunneling into the tubes was evident (Table-3).

In a comparative outlook, through results obtained from different tests applied for both oils, $C$. citratus oil treatments exhibited a significant higher efficacy against $M$. mycophagus (Desneux) in our studies. Literature provides a lot of research work for the use of different plant essential oils and natural monoterpenoids against several other species of subterranean termites but there was no previous evidence for the particular use of $E$. citriodora and $C$. citratus essential oils against $M$. mycophagus (Desneux) as potential termiticidal. However both of these oils along with others have been successfully evaluated as possessing toxicant and repellent components against Formosan subterranean termites ${ }^{20}$. The tunneling and fumigation test results of our study recommend the different concentrations of these oils as competent termite control measure in a closed and limited treatment area as the open air may reduce the efficacy volatility of these oils being the limiting factor. 


\begin{tabular}{|c|c|c|c|c|c|c|c|c|c|}
\hline \multicolumn{10}{|c|}{$\begin{array}{l}\text { TABLE-3 } \\
\text { RESULTS OF DIFFERENT TESTS OF ESSENTIAL OILS OF EUCALYPTUS (Eucalyptus citriodora) AND } \\
\text { LEMONGRASS (Cymbopogon citratus) APPLIED AGAINST WORKERS OF } M \text {. mycophagus (Desneux) }\end{array}$} \\
\hline \multirow{3}{*}{$\begin{array}{c}\text { Test } \\
\text { applied }\end{array}$} & \multirow{3}{*}{ Concentrations } & \multicolumn{8}{|c|}{ Test oils } \\
\hline & & \multicolumn{4}{|c|}{ Eucalyptus citriodora essential Oil } & \multicolumn{4}{|c|}{ Cympobogon citratus essential Oil } \\
\hline & & $\begin{array}{c}\text { Mean } \\
\text { mortality }(\%)\end{array}$ & $\begin{array}{r}\text { Filter pap } \\
\text { (Ave. } \pm\end{array}$ & $\begin{array}{l}\text { r consumption) } \\
\text { SEM, } N=3 \text { ) }\end{array}$ & $\mathrm{LC}_{50}$ & $\begin{array}{c}\text { Mean } \\
\text { mortality }(\%) \\
\end{array}$ & $\begin{array}{r}\text { Filter paper } \\
\text { (Ave. } \pm\end{array}$ & $\begin{array}{l}\text { consumption) } \\
\mathrm{EM}, \mathrm{N}=3 \text { ) }\end{array}$ & LC50 \\
\hline \multirow{6}{*}{$\begin{array}{l}\text { Toxicity } \\
\text { test / } \\
\text { mortality } \\
\text { test }\end{array}$} & $1 \mu \mathrm{g} / 10 \mu \mathrm{L}$ & $23.33 \pm 0.57$ & 0.0 & $0 \pm 0.000$ & \multirow{6}{*}{14.94} & $24.44 \pm 0.33$ & 0.008 & \pm 0.002 & \multirow{6}{*}{13.35} \\
\hline & $5 \mu \mathrm{g} / 10 \mu \mathrm{L}$ & $32.22 \pm 0.67$ & 0.0 & $8 \pm 0.002$ & & $33.33 \pm 0.57$ & 0.007 & \pm 0.002 & \\
\hline & $10 \mu \mathrm{g} / 10 \mu \mathrm{L}$ & $40.00 \pm 1.15$ & 0.0 & $8 \pm 0.002$ & & $42.22 \pm 0.67$ & 0.005 & \pm 0.000 & \\
\hline & $15 \mu \mathrm{g} / 10 \mu \mathrm{L}$ & $50.00 \pm 0.57$ & 0.0 & $7 \pm 0.002$ & & $51.11 \pm 0.88$ & 0.005 & \pm 0.000 & \\
\hline & $25 \mu \mathrm{g} / 10 \mu \mathrm{L}$ & $62.22 \pm 0.67$ & 0.0 & $3 \pm 0.002$ & & $63.33 \pm 0.57$ & 0.002 & \pm 0.002 & \\
\hline & Control & $0.00 \pm 0.00$ & 0.0 & $7 \pm 0.003$ & & $0.00 \pm 0.00$ & 0.017 & \pm 0.003 & \\
\hline \multirow{5}{*}{$\begin{array}{l}\text { Tunne- } \\
\text { ling } \\
\text { bioassay }\end{array}$} & \multicolumn{3}{|c|}{$\begin{array}{l}\text { Percentage distance } \\
\text { crossed at different test } \\
\text { conc. }(\text { Ave. } \pm \mathrm{SEM}, \mathrm{N}=3 \text { ) }\end{array}$} & \multicolumn{2}{|c|}{$\begin{array}{l}\text { Average hours to } \\
\text { cross tubes }(\mathrm{X} \pm \mathrm{SE})\end{array}$} & $\begin{array}{l}\text { Percentage distan } \\
\text { different test col } \\
\text { SEM, N }\end{array}$ & $\begin{array}{l}\text { crossed at } \\
\text { (Ave. } \pm\end{array}$ & \multicolumn{2}{|c|}{$\begin{array}{l}\text { Average hours to cros } \\
\text { tubes }(\mathrm{X} \pm \mathrm{SE})\end{array}$} \\
\hline & $0 \mu \mathrm{g} / \mathrm{g}$ & \multicolumn{2}{|c|}{100} & \multicolumn{2}{|l|}{$24 \pm 0.00$} & 100 & & \multicolumn{2}{|c|}{$24 \pm 0.00$} \\
\hline & $5 \mu \mathrm{g} / \mathrm{g}$ & \multicolumn{2}{|c|}{100} & \multicolumn{2}{|l|}{$24 \pm 0.00$} & 100 & & \multicolumn{2}{|c|}{$24 \pm 0.00$} \\
\hline & $25 \mu \mathrm{g} / \mathrm{g}$ & \multicolumn{2}{|c|}{100} & \multicolumn{2}{|l|}{$26 \pm 2.00$} & 100 & & \multicolumn{2}{|c|}{$28 \pm 2.00$} \\
\hline & $50 \mu \mathrm{g} / \mathrm{g}$ & \multicolumn{2}{|c|}{100} & \multicolumn{2}{|c|}{$28 \pm 2.00$} & 100 & & \multicolumn{2}{|c|}{$50 \pm 2.00$} \\
\hline \multirow{7}{*}{\multicolumn{2}{|c|}{$\begin{array}{l}\text { Fumigation test at a } \\
\text { concentration of } 5 \mathrm{ppm} \\
(\text { Ave. } \pm \mathrm{SEM}, \mathrm{N}=3 \text { ) }\end{array}$}} & \multicolumn{2}{|c|}{ Reading day } & \multicolumn{3}{|c|}{ Mean no. of dead termites } & \multicolumn{3}{|c|}{ Mean no. of dead termites } \\
\hline & & \multicolumn{2}{|c|}{$1 \mathrm{~d}$} & \multicolumn{3}{|c|}{$8.33 \pm 0.57$} & \multicolumn{3}{|c|}{$9.33 \pm 0.57$} \\
\hline & & \multirow{2}{*}{\multicolumn{2}{|c|}{$\begin{array}{l}3 d \\
5 d\end{array}$}} & & $3 \pm 0.5$ & & & $3.33 \pm 0.57$ & \\
\hline & & & & & $3 \pm 0.5$ & & & $7.33 \pm 1.15$ & \\
\hline & & $7 \mathrm{~d}$ & & & $0 \pm 1.0$ & & & $1.00 \pm 1.00$ & \\
\hline & & $9 d$ & & & $0 \pm 1.00$ & & & $5.000 \pm 0.00$ & \\
\hline & & Cont & & & $0 \pm 0.00$ & & & $0.00 \pm 0.00$ & \\
\hline
\end{tabular}

These essential oils with antitermitic properties are the impending natural sources for the development of novel termiticidal with least mammalian toxicity and most environment protection hence should be given priority to isolate the tangible antitermitic constituents and to determine their mode of action against termites.

\section{REFERENCES}

1. H.J.D. Dorman and S.G. Deans, J. Appl. Microbiol., 88, 308 (2000).

2. M.B. Isman, Crop. Protect, 19, 603 (2000).

3. G. Rosell, C. Quero, J. Coll and A. Guerrero, J. Pestic. Sci., 33, 103 (2008).

4. F. Bakkali, S. Averbeck, D. Averbeck and M. Idaomar, Food Chem. Toxicol., 46, 446 (2008).

5. S.V. Phatak and M.R. Heble, Fitoterapia, 73, 32 (2002).

6. I.K. Park and S.C. Shin, J. Agric. Food Chem., 53, 438 (2005).

7. S.T. Chang, S.S. Cheng and S.Y. Wang, J. Chem. Ecol., 27, 717 (2001).

8. M.I. Chaudhry and M. Ahmed, Termites of Pakistan. Identifying, Distributing and Ecological Relationships (Final Technical Report). Pakistan Forest Institute of Peshawar, pp. 13-19 (1972).
9. M.S. Akhtar, Pak. J. Zool., 6, 85 (1974).

10. M.S. Akhtar, Materia. Organ., 18, 277 (1983).

11. F. Manzoor, S.M.A. Rahim, B.M.A. Shiday, S.A. Malik, B. Habibpour, J.R.J. French and F. Jabeen, Afri. J. Environ. Sci. Tech., 4, 11 (2010).

12. A.F.M. Barton, J. Ind. Ecol., 3, 161 (2000).

13. F. Manzoor, N. Naz, S.A. Malik, B.S. Siddiqui, A. Syed and S. Perwaiz, Asian J. Chem., 24, 2069 (2012).

14. K.R. Chauhan and A.K. Raina, in ed.: A.M. Rimando and S.O. Duke, Modified Vetiver Oil: Economic Biopesticide. Natural Products for Pest Management, ACS Symposium Series, 27, 210 (2006).

15. A. Raina, J. Bland, M. Doolittle, A. Lax, R. Boopathy and M. Folkins, J. Econ. Entomol., 100, 880 (2007).

16. R.N. Chopra, Indeginous Drugs of India, Academic Publishers, Calcutta, India, edn. 2 (1994).

17. K. Jaimand, M.H. Assareh and M.B. Rezaee, Iran. J. Pharm. Res., 1, 73 (2006).

18. S.S. Basak and F. Candan, J. Iran. Chem. Soc., 7, 216 (2010).

19. E.E. Aziz and M.H. Abbass, Am.-Eur. J. Agric. Environ. Sci., 8, 411 (2010).

20. B.C.R. Zhu, G. Henderson, F. Chen, H. Fei and R.A. Laine, J. Chem. Ecol., 27, 1617 (2001). 